\title{
PREDICTION OF THE CHEMICAL NON-HOMOGENEITY OF 30MnVS6 BILLETS WITH GENETIC PROGRAMMING
}

\author{
NAPOVEDOVANJE NEHOMOGENOSTI KEMIJSKE SESTAVE PRI \\ GREDICAH 30MnVS6 S POMOČJO GENETSKEGA \\ PROGRAMIRANJA
}

\author{
Miha Kovačič, Damir Novak \\ Štore Steel d.o.o., Železarska cesta 3, 3220 Štore, Slovenia \\ miha.kovacic@store-steel.si \\ Prejem rokopisa - received: 2014-11-13; sprejem za objavo - accepted for publication: 2015-02-18
}

doi:10.17222/mit.2014.280

\begin{abstract}
Štore Steel Ltd. is a small and flexible steel plant. The plant also produces the 30MnVS6 steel grade, which is used for crack connection rods in the automotive industry. The chemical elements are not uniformly distributed over the billet cross-sections, consequently influencing the final product properties. The chemical distribution depends mainly on the casting parameters. The article presents an attempt at predicting the chemical non-homogeneity of 30MnVS6 billets. With respect to the chemical-element distribution (\% C, \% Si, \% Mn, \% V, \% S) over the billet cross-sections and the casting parameters (casting speed, casting temperature, meniscus level), several models for the chemical non-homogeneity prediction were developed by means of the genetic-programming method. The results show that the most influential parameter is the casting speed. The results of modeling can be practically implemented in order to reduce the chemical non-homogeneity of the billets. Keywords: steel, casting, billets, chemical composition, non-homogeneity, modelling, genetic programming
\end{abstract}

Štore Steel je majhna, a prilagodljiva jeklarna. Proizvajajo tudi jeklo 30MnVS6, ki se uporablja za ojnice, ki se izdelujejo z lomljenjem, za avtomobilsko industrijo. Kemijski elementi niso enakomerno porazdeljeni po prerezu gredice, kar posledično vpliva na lastnosti končnega izdelka. Razporeditev kemijskih elementov je najbolj odvisna od parametrov vlivanja. V članku je predstavljen poskus napovedovanja kemijske nehomogenosti gredic jekla 30MnVS6. Glede na razporeditve kemijskih elementov ( $\% \mathrm{C}, \% \mathrm{Si}, \% \mathrm{Mn}, \% \mathrm{~V}, \% \mathrm{~S}$ ) po prerezu gredice in parametre vlivanja (hitrost vlivanja, temperatura vlivanja, nivo taline), se je izdelalo več modelov, za napovedovanje kemijske nehomogenosti gredic, s pomočjo metode genetskega programiranja. Rezultati kažejo, da je najvplivnejši parameter hitrost vlivanja. Rezultati modeliranja se lahko uporabijo v praksi z namenom zmanjšanja kemijske nehomogenosti gredic.

Ključne besede: jeklo, litje, gredice, kemijska sestava, nehomogenost, modeliranje, genetsko programiranje

\section{INTRODUCTION}

Due to a gradual solidification during the continuous casting of steel, chemical-composition variations occur, which influence the cast and, consequently, the processed-material properties; therefore, their optimization is essential. ${ }^{1}$

In the previous research ${ }^{2}$, the chemical composition of the cross-section of a high-grade pipeline slab was measured point by point. The results indicated that a negative segregation inside the central line is more severe than that outside the central line, and that the highest positive segregation of the elements appears close to the inner sides of the negative segregation strips. In addition, the segregation of the elements in the central area is higher than that in the outer and inner arc areas.

Article $^{3}$ discusses the manufacturing of bearing steels of low distortion potential. The 100Cr6 steel billets were spray formed to achieve metallurgical homogeneity. The microstructures and properties of the billets produced under different thermal conditions were studied and evaluated. A heat-transfer model for a growing billet was established in order to investigate the thermal profiles of the billets during spray forming. An apparent correlation between the cooling and solidification conditions of the deposit and its metallurgical properties was revealed by means of a numerical simulation and an experiment.

Gheorghies et al. ${ }^{4}$ developed a theoretical model that was adapted for studying the steel continuous-casting technology. The model is based on the system theory, considering input/output, command and control parameters. It can be used to describe the physicochemical processes, thermal processes, chemical processes and the characteristics of the cast material on the basis of the above-mentioned stages.

In the research described in ${ }^{5}$ LIBS scanning measurements were performed on samples displaying segregation. The resulting quantified elemental maps correlated very well with the data obtained with the conventional methods.

In research ${ }^{6}$ an artificial-intelligence analyzer of the mechanical properties of rolled steel bars was proposed using neural networks. The complex correlation among the steel bar properties, the billet compositions and the control parameters of manufacturing was developed. The developed analyzer could be used in practice in order to improve the steel quality. 
Hwang et al. ${ }^{7}$ tried to minimize the center segregation with the help of a developed coupled temperature/displacement finite-element model. The center segregation, center porosity, homogeneity of elements and equiaxed crystal zone were improved.

This paper discusses the use of the genetic-programming method for predicting the chemical nonhomogeneity of the 30MnVS6 billets, used in rolled conditions, for forging crack connection rods in the automotive industry. Genetic programming is an evolutionary computation-based methodology of artificial intelligence (AI); it is similar to the genetic algorithm (GA). ${ }^{8}$ Genetic programming (GP) is capable of solving many different problems in industry; however, it uses different natural phenomena in comparison to many other AI-based approaches, such as artificial neural networks (ANN), swarm intelligence (SI) and gravitational search algorithm (GSA). For a comparison of the practical uses of the above-mentioned methods in industrial applications see reference literature, for example. ${ }^{9-12}$

The problem is stated in section 2 . In the subsequent section the experimental background and, afterwards, the essence of the chemical non-homogeneity prediction are presented. The analysis of the modelling results are presented in section 4 and, finally, the main contributions of the research and the guidelines for further research are given in the last section.

\section{EXPERIMENTAL BACKGROUND}

Steelmaking begins with scrap melting in an electric-arc furnace. The melting bath, which is heated up to the tapping temperature required for the further treatment procedure, is discharged into a casting ladle.

After achieving the proper melt temperature in the melting bath, the billets are continuously cast. The melt flows through a sliding-gate system and ladle shroud towards a tundish.

After filling up the tundish with the help of the mold-filling system with tundish stoppers and submerged pouring tubes, the casting is established. The billets, with a square section of $180 \mathrm{~mm}$, are cast. After reaching a certain melting-bath level, the potentiometer starts the flattening system, which drags the billet out of

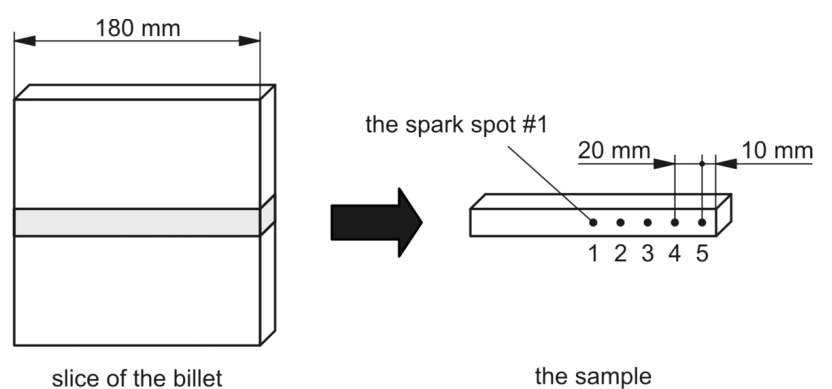

Figure 1: Sample from the billet slice with the spark spots Slika 1: Vzorec iz rezine, odrezane iz gredice, s točkami obžiga the mold. In this way, the continuous casting is established. Each billet goes through the cooling zone toward the gas cutters, where it is cut and laid off onto the cooling bed.

The data for the analysis was collected on the basis of 30 consecutively cast batches of the 30MnVS6 steel in Štore Steel Ltd. (Table 1) from May to September 2011. The data was taken from the technological documentation of the cast batches and from the chemical archive. The goal was to get as wide a range of influential parameters as possible, namely:

- the contents of $\mathrm{C}, \mathrm{Si}, \mathrm{Mn}, \mathrm{S}$ and $\mathrm{V}$ in the tundish $(w / \%)$

- the average melt temperature in the tundish $\left({ }^{\circ} \mathrm{C}\right)$

- the average meniscus level ( $\mathrm{mm})$

- the average casting speed $(\mathrm{m} / \mathrm{min})$

- the average strand temperature in the cooling zone $\left({ }^{\circ} \mathrm{C}\right)$.

From each of the selected 30 batches, a billet was taken from the middle of the casting and a slice was cut out. For the chemical analysis, optical emission spectroscopy was used (instrument SPECTRO LAVMC12A). Five spark spots were used for determining the chemical non-homogeneity (Figure 1).

For example, the carbon content obtained from five spark spots on the sample from batch number 1 is presented in Figure 2.

The carbon non-homogeneity $C_{\mathrm{n}-\mathrm{h}}$ can be easily calculated:

$$
C_{\mathrm{n}-\mathrm{h}}=\frac{\sum_{i=1}^{5} C_{i}}{\bar{C}}
$$

where $i$ is the individual spot size and $\bar{C}$ is the average of all five carbon-content values for each spot:

$$
\bar{C}=\frac{\sum_{i=1}^{5} C_{i}}{5}
$$

Similarly, the non-homogeneity for each individual chemical element can be calculated.

The experimental data and the non-homogeneities for individual chemical elements are presented in Table $\mathbf{1 .}$

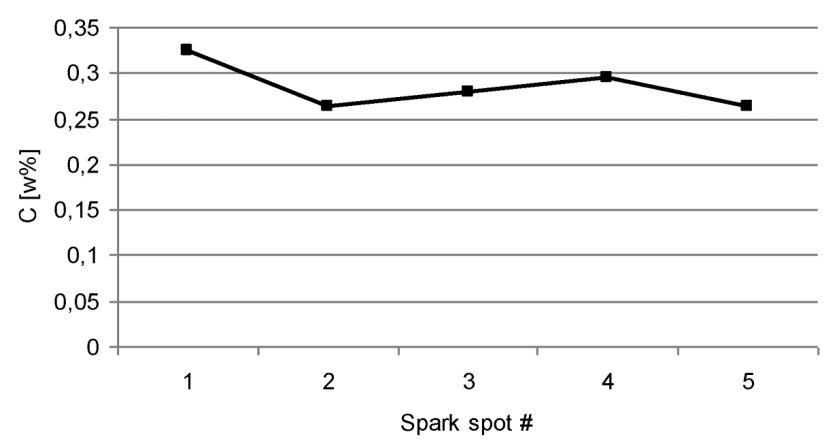

Figure 2: Carbon content at each spark spot

Slika 2: Vsebnost ogljika na posamičnem mestu obžiga 


\section{MODELLING OF CHEMICAL NON-HOMO- GENEITY WITH GENETIC PROGRAMMING}

Genetic programming is probably the most general evolutionary optimization method $^{8}$ and it has already been found useful for several different applications in Štore Steel Ltd. ${ }^{13-17}$. The organisms that undergo an adaptation are in fact mathematical expressions (models) for chemical non-homogeneity, consisting of the available function genes (i.e., basic arithmetical functions) and terminal genes (i.e., independent input parameters and random floating-point constants). In our case, the models consist of the function genes of addition $(+)$, subtraction (-), multiplication (*) and division (/), while terminal genes include:
- the contents of $\mathrm{C}(C), \mathrm{Si}(S I), \mathrm{Mn}(M N), \mathrm{S}(S)$ and $\mathrm{V}$ $(V)$ in the tundish

- the average melt temperature in the tundish $(T M)$

- the average meniscus level $(M L)$

- the average casting speed (SPEED) and

- the average strand temperature in the cooling zone $(T C)$.

Random computer programs of various forms and lengths are generated by means of selected genes at the beginning of the simulated evolution. Afterwards, the varying of the computer programs during several iterations, known as generations, is performed by means of genetic operations. For the progress of the population, only the reproduction and crossover are sufficient. A new generation is obtained after the completion of various

Table 1: Experimental data

Tabela 1: Eksperimentalni podatki

\begin{tabular}{|c|c|c|c|c|c|c|c|c|c|c|c|c|c|c|c|}
\hline 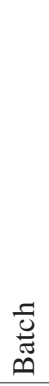 & $0 \stackrel{2}{3}$ & $i \frac{2}{3}$ & $\sum \frac{\sqrt{2}}{3}$ & $\operatorname{si} \frac{2}{3}$ & $>\frac{2}{3}$ & 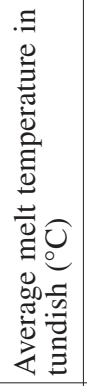 & 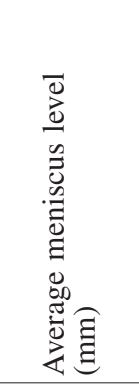 & 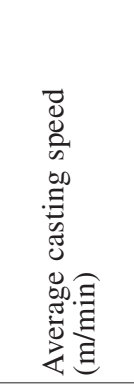 & 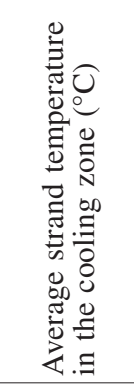 & 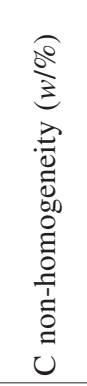 & 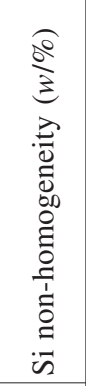 & 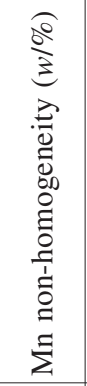 & 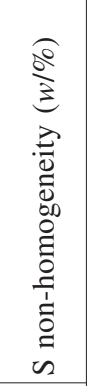 & $\begin{array}{l}20 \\
3 \\
3 \\
\frac{0}{0} \\
0 \\
00 \\
0 \\
0 \\
0 \\
\frac{1}{1} \\
0 \\
0 \\
>\end{array}$ & 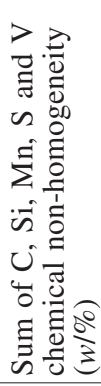 \\
\hline 1 & 0.29 & 0.55 & 1.43 & 0.05 & 0.09 & 1543 & 74.53453 & 1.135516 & 1092.7 & 35.28 & 34.30 & 34.17 & 31.52 & 33.57 & 168.83 \\
\hline 2 & 0.29 & 0.58 & 1.44 & 0.058 & 0.1 & 1548 & 76.11422 & 1.128306 & 1091.669 & 5.61 & 1.77 & 2.19 & 10.81 & 2.41 & 22.79 \\
\hline 3 & 0.28 & 0.59 & 1.43 & 0.05 & 0.09 & 1543 & 74.34058 & 1.114705 & 1093.121 & 10.32 & 6.98 & 7.49 & 19.51 & 6.71 & 51.01 \\
\hline 4 & 0.3 & 0.6 & 1.43 & 0.051 & 0.1 & 1542 & 74.38523 & 1.148343 & 1110.401 & 22.01 & 23.24 & 24.73 & 22.12 & 24.72 & 116.82 \\
\hline 5 & 0.29 & 0.59 & 1.46 & 0.052 & 0.1 & 1545 & 74.55143 & 1.143362 & 1100.045 & 40.36 & 39.00 & 38.98 & 27.54 & 36.84 & 182.72 \\
\hline 6 & 0.29 & 0.57 & 1.45 & 0.051 & 0.11 & 1544 & 74.62807 & 1.144693 & 1100.519 & 33.73 & 34.43 & 35.10 & 38.21 & 34.41 & 175.89 \\
\hline 7 & 0.29 & 0.58 & 1.47 & 0.05 & 0.1 & 1551 & 74.61523 & 1.115993 & 1092.786 & 33.68 & 38.06 & 38.73 & 36.24 & 40.04 & 186.76 \\
\hline 8 & 0.3 & 0.57 & 1.43 & 0.058 & 0.1 & 1530 & 74.5125 & 1.136773 & 1123.988 & 32.08 & 35.08 & 33.65 & 26.26 & 33.60 & 160.68 \\
\hline 9 & 0.29 & 0.58 & 1.45 & 0.05 & 0.1 & 1548 & 74.49432 & 1.136511 & 1123.195 & 22.17 & 22.17 & 20.65 & 23.32 & 20.46 & 108.76 \\
\hline 10 & 0.3 & 0.57 & 1.45 & 0.059 & 0.1 & 1536 & 74.46816 & 1.139951 & 1121.601 & 5.64 & 5.86 & 6.76 & 22.05 & 8.12 & 48.43 \\
\hline 11 & 0.3 & 0.63 & 1.44 & 0.059 & 0.11 & 1538 & 74.54645 & 1.142406 & 1121.38 & 33.94 & 33.88 & 31.97 & 27.54 & 33.80 & 161.13 \\
\hline 12 & 0.29 & 0.58 & 1.43 & 0.06 & 0.1 & 1553 & 74.59237 & 1.116969 & 1116.805 & 40.13 & 40.46 & 39.14 & 36.08 & 38.92 & 194.72 \\
\hline 13 & 0.29 & 0.58 & 1.43 & 0.055 & 0.1 & 1549 & 74.52381 & 1.117879 & 1111.379 & 24.40 & 28.32 & 26.53 & 42.90 & 29.29 & 151.43 \\
\hline 14 & 0.3 & 0.55 & 1.43 & 0.045 & 0.09 & 1544 & 74.4881 & 1.133849 & 1105.889 & 25.87 & 26.01 & 25.05 & 23.44 & 23.03 & 123.41 \\
\hline 15 & 0.29 & 0.61 & 1.45 & 0.052 & 0.1 & 1549 & 74.32708 & 1.126732 & 1108.002 & 19.93 & 23.92 & 23.15 & 23.20 & 24.09 & 114.29 \\
\hline 16 & 0.28 & 0.6 & 1.42 & 0.053 & 0.1 & 1541 & 74.39798 & 1.150479 & 1118.254 & 32.04 & 33.77 & 32.41 & 26.27 & 33.59 & 158.09 \\
\hline 17 & 0.28 & 0.57 & 1.46 & 0.06 & 0.1 & 1548 & 74.36111 & 1.133132 & 1120.187 & 21.63 & 22.42 & 20.75 & 24.63 & 20.04 & 109.46 \\
\hline 18 & 0.28 & 0.58 & 1.44 & 0.058 & 0.1 & 1543 & 74.37007 & 1.165916 & 1119.613 & 32.89 & 33.99 & 33.22 & 30.33 & 33.84 & 164.27 \\
\hline 19 & 0.28 & 0.59 & 1.45 & 0.05 & 0.11 & 1547 & 74.39048 & 1.130368 & 1123.507 & 35.47 & 39.57 & 38.79 & 39.55 & 39.49 & 192.87 \\
\hline 20 & 0.29 & 0.6 & 1.45 & 0.058 & 0.1 & 1546 & 74.49107 & 1.134441 & 1115.035 & 12.77 & 7.91 & 6.69 & 12.62 & 6.95 & 46.94 \\
\hline 21 & 0.29 & 0.63 & 1.48 & 0.06 & 0.1 & 1545 & 74.50678 & 1.139199 & 1119.22 & 23.28 & 23.68 & 23.88 & 14.81 & 23.63 & 109.29 \\
\hline 22 & 0.29 & 0.6 & 1.45 & 0.059 & 0.1 & 1542 & 74.49815 & 1.144132 & 1127.137 & 39.29 & 40.28 & 39.51 & 38.89 & 38.91 & 196.88 \\
\hline 23 & 0.29 & 0.6 & 1.42 & 0.052 & 0.1 & 1547 & 74.3956 & 1.110585 & 1126.187 & 7.69 & 6.32 & 6.86 & 15.46 & 5.16 & 41.48 \\
\hline 24 & 0.29 & 0.58 & 1.42 & 0.056 & 0.1 & 1558 & 74.46951 & 1.092817 & 1124.571 & 9.03 & 8.00 & 7.44 & 21.41 & 7.21 & 53.10 \\
\hline 25 & 0.29 & 0.61 & 1.43 & 0.06 & 0.1 & 1555 & 74.32818 & 1.082388 & 1120.363 & 23.68 & 20.73 & 21.52 & 25.79 & 22.54 & 114.26 \\
\hline 26 & 0.28 & 0.61 & 1.46 & 0.052 & 0.11 & 1543 & 74.47059 & 1.125766 & 1132.468 & 3.85 & 0.88 & 1.50 & 6.82 & 0.92 & 13.97 \\
\hline 27 & 0.29 & 0.59 & 1.44 & 0.052 & 0.1 & 1557 & 74.41155 & 1.103096 & 1116.793 & 21.61 & 23.94 & 23.45 & 17.61 & 22.57 & 109.19 \\
\hline 28 & 0.28 & 0.58 & 1.44 & 0.055 & 0.1 & 1546 & 74.31526 & 1.132103 & 1133.436 & 23.16 & 21.12 & 21.20 & 26.43 & 20.55 & 112.46 \\
\hline 29 & 0.29 & 0.58 & 1.44 & 0.055 & 0.1 & 1556 & 74.43371 & 1.101385 & 1128.988 & 32.11 & 37.68 & 39.59 & 42.06 & 38.09 & 189.53 \\
\hline 30 & 0.29 & 0.62 & 1.45 & 0.052 & 0.1 & 1548 & 74.42917 & 1.09335 & 1126.615 & 21.81 & 23.84 & 23.54 & 17.37 & 22.90 & 109.47 \\
\hline
\end{tabular}


computer programs and this generation is then evaluated and compared with the experimental data.

The process of changing and evaluating organisms is repeated until the termination criterion of the process is fulfilled. This was the prescribed maximum number of generations.

For the process of simulated evolutions, the following evolutionary parameters were selected: the size of the population of organisms - 500; the greatest number in a generation -100 ; the reproduction probability -0.4 ; the crossover probability -0.6 ; the greatest permissible depth of population (6); the greatest permissible depth, after the operation, of the crossover of two organisms 10; and the smallest permissible depth of organisms when generating new organisms -2 . Genetic operations of reproduction and crossover were used. For the selection of the organisms, the tournament method with tournament size 7 was used. For the model, the fitness average relative deviation from the monitored data was selected. It is defined as:

$$
\Delta=\frac{\sum_{i=1}^{n} \frac{\left|E_{i}-P_{i}\right|}{E_{i}}}{n}
$$

where $n$ is the size of the monitored data, $E_{i}$ and $P_{i}$ are the actual (experimental) and predicted sums of the $C$, $\mathrm{Si}, \mathrm{Mn}, \mathrm{S}$ and $\mathrm{V}$ chemical non-homogeneity, respectively.

We have developed 100 independent civilizations of mathematical models for the chemical non-homogeneity prediction. Each civilization had its most successful organism - mathematical model. The most successful organism of all the civilizations is presented here:

$$
C+\left(\frac{-1+S P E E D}{S}+\frac{1}{S P E E D}-S P E E D+\frac{V^{2}}{(-1+S P E E D) \text { SPEED }}-\right.
$$

$$
\begin{aligned}
& \frac{-1+\text { SPEED }}{\left(\text { SPEED }-\frac{v}{\left(S P E E D-\frac{1}{v}\right)\left(1+S P E E D-\frac{V}{s}\right)}\right)\left(C+\frac{1+S P E E D-\frac{v}{s}}{C\left(-\frac{2(-1 \text { SPEED }}{\frac{\text { SPEED }}{S}}+\text { SPEED }\right)}\right)\left(\text { SPEED }-\frac{1+\text { SPEED }-\frac{v}{s}}{v}\right)}- \\
& \text { SPEED }-\frac{V}{S}+\frac{C\left(1+\text { SPEED }-\frac{V}{s}\right)}{V}
\end{aligned}
$$

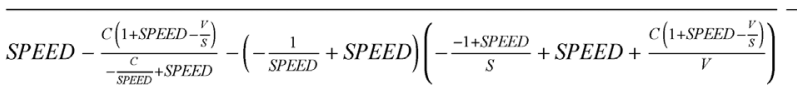

$$
\begin{aligned}
& \left.\frac{V}{\left(\frac{1}{S P E E D}-\frac{V}{S}+\frac{1+S P E E D-\frac{V}{s}}{C}\right)\left(2 S P E E D-\frac{V}{S P E E D-\frac{C V}{-1+S P E E D}}-\frac{V}{C+\left(\text { SPEED }-\frac{V}{s}\right)\left(1+S P E E D-\frac{V}{s}\right)}\right)}\right) \\
& \left(2 \text { SPEED }-\frac{V}{S}-\frac{V}{S P E E D-\frac{V}{S P E E D}-\frac{V}{C+\left(1+S P E E D-\frac{V}{S}\right)\left(-\frac{1}{C}+S P E E D-\frac{V}{\text { SPEED }}\right)}}\right)
\end{aligned}
$$

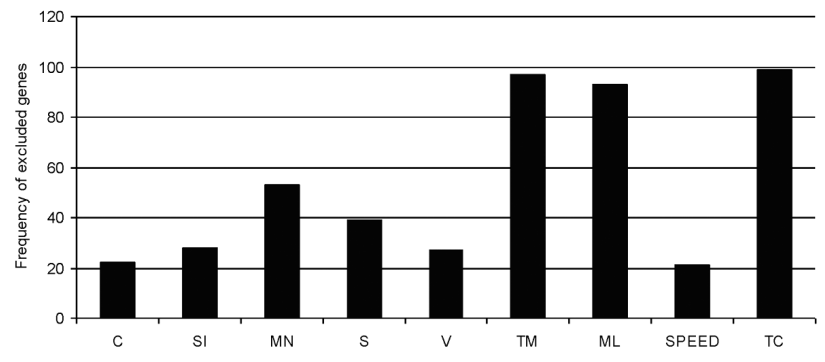

Figure 3: Frequency of genes excluded from the best 100 mathematical models for chemical non-homogeneity prediction

Slika 3: Frekvenca izločenih genov na podlagi najboljših 100-ih matematičnih modelov za napovedovanje kemijske nehomogenosti

with an average relative deviation of $27.82 \%$. It is obvious that only $C$ (the content of $\mathrm{C}$ in the tundish), $S$ (the content of $\mathrm{S}$ in the tundish), $V$ (the content of $\mathrm{V}$ in the tundish) and SPEED (the average casting speed) are included in the model.

\section{ANALYSIS OF THE RESULTS}

A randomly driven process builds the fittest and the most complex models from generation to generation and uses the ingredients that are the most suitable for an experimental environment adaptation. For curiosity's sake, the analysis of the genes (parameters) excluded from the models is presented in the next figure (Figure 3).

Based on the number of the genes excluded from 100 mathematical models, we may make assumptions about the influence of the parameters on the chemical nonhomogeneity. It is clear from the figure that out of 100 genetically obtained mathematical models only 21 models do not include the parameter of the average casting speed (SPEED) and fewer than 30 out of 100 models do not have the parameter of the contents of $\mathrm{C}$ $(C), \mathrm{Si}(S I)$, and $\mathrm{V}(V)$ included in the tundish. We can, therefore, speculate that they are probably the most important parameters influencing the chemical non-homogeneity.

Figure 4 shows the calculated influences of individual parameters on the chemical non-homogeneity using

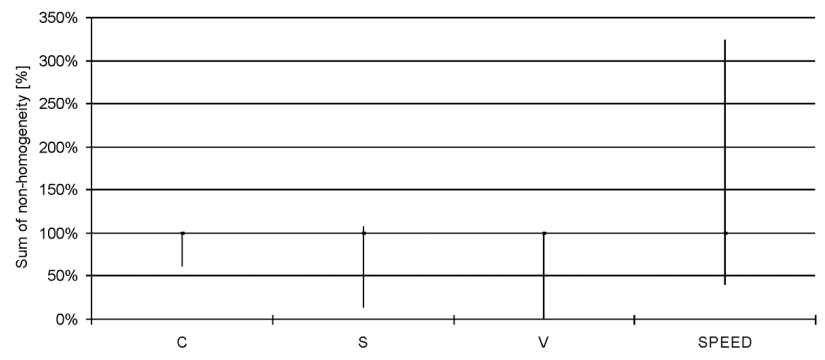

Figure 4: Calculated influences of individual parameters on chemical non-homogeneity while separately changing them within the range from Table 1

Slika 4: Izračunani vplivi posamičnih parametrov na kemijsko nehomogenost pri le-njihovem spreminjanju znotraj območja, navedenega v tabeli 1 


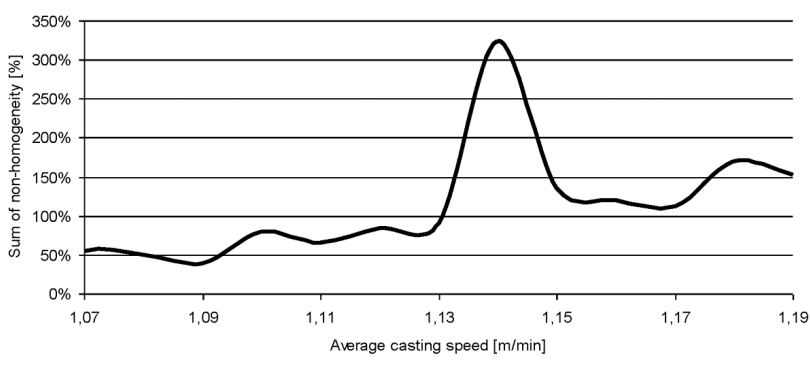

Figure 5: Calculated correlation between the casting speed and chemical non-homogeneity while separately changing the average casting speed

Slika 5: Izračunana korelacija med livno hitrostjo in kemijsko nehomogenostjo pri spreminjanju povprečne livne hitrosti

the developed model (Equation (4)) while separately changing the individual parameters within the range from Table 1. The dashes at individual total decarburization ranges represent the calculated average chemical non-homogeneity of all 30 collected samples, which is $98.88 \%$. The average chemical non-homogeneity value of the collected data is $122.96 \%$.

Figure 5 shows the calculated correlation between the casting speed and the chemical non-homogeneity while separately changing the average casting speed. This can be calculated and, consequently, used for individual influential parameters as a tool for selecting the optimal casting speed. It should be noted that the average value of the average casting speed for all 30 cases is $1.127 \mathrm{~m} / \mathrm{min}$ (a standard deviation of 0.0191 $\mathrm{m} / \mathrm{min}$ ).

\section{CONCLUSION}

The purpose of this research was to predict the chemical non-homogeneity of 30MnVS6 steel grade billets. The data for the analysis was collected on the basis of 30 consecutively cast batches. The distribution of the chemical elements ( $\% \mathrm{C}, \% \mathrm{Si}, \% \mathrm{Mn}, \% \mathrm{~V}, \% \mathrm{~S})$ over the billet cross-sections and the casting parameters (casting speed, casting temperature, meniscus level) were gathered. On the basis of the gathered data, several models for predicting the chemical non-homogeneity were developed by means of the genetic-programming method. There were 100 different models developed and only the best one was used for the chemical non-homogeneity prediction. The relative average deviation between the actual and the predicted scrap was $27.82 \%$. In addition, the frequencies of the genes excluded from the best 100 mathematical models for the chemical nonhomogeneity prediction were analyzed. The results show that the parameters influencing the chemical non-homogeneity the most are the casting speed and the contents of $\mathrm{C}, \mathrm{Si}$ and $\mathrm{V}$ in the melt. Also, the influences of individual parameters on the chemical non-homogeneity were calculated while separately changing individual parameters, using the best genetically developed model. The calculation shows that the variation in the speed changes the chemical non-homogeneity from 39 to 324 $\%$, while the calculated average chemical non-homogeneity of all 30 collected samples is $98.88 \%$. Finally, the correlation between the casting speed and the chemical non-homogeneity was calculated while separately changing the average casting speed. The results of the research can be used as a tool for selecting the optimum casting speed. In the future, a larger sample size will be used and a methodology for the other steel grades will be implemented.

\section{REFERENCES}

${ }^{1}$ W. R. Irving, Continuous casting of steel, Institute of Materials, London 1993

${ }^{2}$ J. Liu, Y. Bao, X. Dong, T. Li, Y. Ren, S. Zhang, Distribution and segregation of dissolved elements in pipeline slab, Journal of University of Science and Technology Beijing, Mineral, Metallurgy, Material, 14 (2007) 3, 212-218, doi:10.1016/S1005-8850(07) 60041-3

${ }^{3}$ C. Cui, U. Fritsching, A. Schulz, R. Tinscher, K. Bauckhage, P. Mayr, Spray forming of homogeneous $100 \mathrm{Cr} 6$ bearing steel billets, Journal of Materials Processing Technology, 186 (2005) 3, 496-504, doi:10.1016/j.jmatprotec.2005.02.250

${ }^{4}$ C. Gheorghies, I. Crudu, C. Teletin, C. Spanu, Theoretical Model of Steel Continuous Casting Technology, Journal of Iron and Steel Research, 16 (2009) 1, 12-16, doi:10.1016/S1006-706X(09)60003-0

${ }^{5}$ F. Boué-Bigne, Laser-induced breakdown spectroscopy applications in the steel industry: Rapid analysis of segregation and decarburization, Spectrochimica Acta Part B: Atomic Spectroscopy, 63 (2008) 10, 1122-1129, doi:10.1016/j.sab.2008.08.014

${ }^{6}$ W. Wang, X. Hu, L. Ning, R. Bülte, W. Bleck, Improvement of center segregation in high-carbon steel billets using soft reduction, Journal of University of Science and Technology Beijing, Mineral, Metallurgy, Material, 13 (2006) 6, 490-496, doi:10.1016/S10058850(06)60100-X

${ }^{7}$ R. C. Hwang, Y. J. Chen, H. C. Huang, Artificial intelligent analyzer for mechanical properties of rolled steel bar by using neural networks, Expert Systems with Applications, 37 (2010) 4, 3136-3139, doi:10.1016/j.eswa.2009.09.069

${ }^{8}$ J. R. Koza, Genetic programming III, Morgan Kaufmann, San Francisco 1999

${ }^{9}$ M. Hrelja, S. Klancnik, T. Irgolic, M. Paulic, Z. Jurkovic, J. Balic, M. Brezocnik, Particle swarm optimization approach for modelling a turning process, Advances in Production Engineering \& Management, 9 (2014) 1, 21-30, doi:10.14743/apem2014.1.173

${ }^{10}$ M. Hrelja, S. Klancnik, J. Balic, M. Brezocnik, Modelling of a turning process using the gravitational search algorithm, International Journal of Simulation Modelling, 13 (2014) 1, 30-41, doi:10.2507/IJSIMM13(1)3.248

${ }^{11}$ M. Chandrasekaran, D. Devarasiddappa, Artificial neural network modeling for surface roughness prediction in cylindrical grinding of Al-SiCp metal matrix composites and ANOVA analysis, Advances in Production Engineering \& Management, 9 (2014) 2, 59-70, doi:10.14743/apem2014.2.176

${ }^{12}$ N. Senthilkumar, T. Tamizharasan, V. Anandakrishnan, An ANN approach for predicting the cutting inserts performances of different geometries in hard turning, Advances in Production Engineering \& Management, 8 (2013) 4, 231-241, doi:10.14743/apem2013.4.170

${ }^{13}$ M. Kovačič, B. Šarler, Genetic programming prediction of the natural gas consumption in a steel plant, Energy, 66 (2014) 1, 273-284, doi:10.1016/j.energy.2014.02.001

${ }^{14}$ M. Kovačič, B. Jurjovec, L. Krajnc, Ladle nozzle opening and genetic programming, Mater. Tehnol., 48 (2014) 1, 23-26 
${ }^{15}$ M. Kovačič, S. Senčič, Modeling of PM10 emission with genetic programming, Mater. Tehnol., 46 (2012) 5, 453-457

${ }^{16}$ M. Kovačič, B. Šarler, Application of the genetic programming for increasing the soft annealing productivity in steel industry, Materials and Manufacturing Processes, 24 (2009) 3, 369-374, doi:10.1080/ 10426910802679634

${ }^{17}$ M. Kovačič, Genetic programming and Jominy test modeling, Materials and Manufacturing Processes, 24 (2009) 7, 806-808, doi:10.1080/10426910902841050 